\title{
Intensive nitrogen loss over the Omani Shelf due to anammox coupled with dissimilatory nitrite reduction to ammonium
}

\author{
Marlene M Jensen ${ }^{1,6,7}$, Phyllis Lam ${ }^{1,7}$, Niels Peter Revsbech², Birgit Nagel $^{3}$, Birgit Gaye ${ }^{4}$, \\ Mike SM Jetten ${ }^{5}$ and Marcel MM Kuypers ${ }^{1}$ \\ ${ }^{1}$ Department of Biogeochemistry, Max Planck Institute for Marine Microbiology, Bremen, Germany; ${ }^{2}$ Institute \\ of Biological Sciences, University of Aarhus, Aarhus, Denmark; ${ }^{3}$ Institute of Coastal Research, GKSS \\ Research Center, Geesthacht, Germany; ${ }^{4}$ Institute of Biogeochemistry and Marine Chemistry, University of \\ Hamburg, Hamburg, Germany and ${ }^{5}$ Department of Microbiology, IWWR, Radbound University Nijmegen, \\ Nijmegen, The Netherlands
}

\begin{abstract}
A combination of stable isotopes $\left({ }^{15} \mathrm{~N}\right)$ and molecular ecological approaches was used to investigate the vertical distribution and mechanisms of biological $\mathrm{N}_{2}$ production along a transect from the Omani coast to the central-northeastern (NE) Arabian Sea. The Arabian Sea harbors the thickest oxygen minimum zone (OMZ) in the world's oceans, and is considered to be a major site of oceanic nitrogen $(\mathrm{N})$ loss. Short $(<48 \mathrm{~h})$ anoxic incubations with ${ }^{15} \mathrm{~N}$-labeled substrates and functional gene expression analyses showed that the anammox process was highly active, whereas denitrification was hardly detectable in the OMZ over the Omani shelf at least at the time of our sampling. Anammox was coupled with dissimilatory nitrite reduction to ammonium (DNRA), resulting in the production of double- ${ }^{15} \mathrm{~N}$-labeled $\mathrm{N}_{2}$ from ${ }^{15} \mathrm{NO}_{2}^{-}$, a signal often taken as the lone evidence for denitrification in the past. Although the central-NE Arabian Sea has conventionally been regarded as the primary $\mathrm{N}$-loss region, low potential $\mathrm{N}$-loss rates at sporadic depths were detected at best. $\mathrm{N}$-loss activities in this region likely experience high spatiotemporal variabilities as linked to the availability of organic matter. Our finding of greater $\mathrm{N}$-loss associated with the more productive Omani upwelling region is consistent with results from other major OMZs. The close reliance of anammox on DNRA also highlights the need to take into account the effects of coupling $\mathrm{N}$-transformations on oceanic $\mathrm{N}$-loss and subsequent $\mathrm{N}$-balance estimates.

The ISME Journal (2011) 5, 1660-1670; doi:10.1038/ismej.2011.44; published online 21 April 2011

Subject Category: geomicrobiology and microbial contributions to geochemical cycles

Keywords: anammox; central-northeastern Arabian Sea; denitrification; functional gene expression; marine nitrogen loss; oxygen minimum zone
\end{abstract}

\section{Introduction}

Nitrate is the highest energy-conserving oxidant for respiration after oxygen. In oxygen-deficient seawater, nitrate is generally believed to be reduced in a stepwise manner to $\mathrm{N}_{2} \mathrm{O}$ or $\mathrm{N}_{2}\left(2 \mathrm{NO}_{3}^{-} \rightarrow 2 \mathrm{NO}_{2}^{-} \rightarrow\right.$ $2 \mathrm{NO} \rightarrow \mathrm{N}_{2} \mathrm{O} \rightarrow \mathrm{N}_{2}$ ) for the respiratory oxidation of organic matter. Known as heterotrophic denitrification, this process has been considered an important factor in the global N-loss from the ocean (Naqvi, 1987; Gruber and Sarmiento, 1997; Codispoti et al.,

Correspondence: MM Jensen or P Lam, Department of Biogeochemistry, Max Planck Institute for Marine Microbiology, Celciusstrasse 1, 28359 Bremen, Germany.

E-mail: mmj@biology.sdu.dk or plam@mpi-bremen.de

${ }^{6}$ Current address: Nordic Center for Earth Evolution and Institute of Biology, University of Southern Denmark, Campusvej 55, 5230 Odense M, Denmark.

${ }^{7}$ These authors contributed equally to this work.

Received 4 October 2010; revised 28 February 2011; accepted 28 February 2011; published online 21 April 2011
2001), affecting indirectly biological productivity and thus sequestration of atmospheric $\mathrm{CO}_{2}$ (Capone, 2000; Gruber, 2004). The major oxygen minimum zones (OMZs) in the world, found in the Arabian Sea and the eastern tropical North and South Pacific, are responsible for $20-40 \%$ of global N-loss from the oceans, whereas $10-20 \%$ is thought to occur in the Arabian Sea (Naqvi, 1987; Codispoti et al., 2001; Gruber, 2004; Devol et al., 2006). Recent findings from incubation experiments with ${ }^{15} \mathrm{~N}$ labeled compounds indicated substantial N-loss due to anammox $\left(\mathrm{NH}_{4}^{+}+\mathrm{NO}_{2}^{-} \rightarrow \mathrm{N}_{2}+2 \mathrm{H}_{2} \mathrm{O}\right)$ in the OMZs off Peru, Chile and Namibia, whereas denitrification was generally below detection (Kuypers et al., 2005; Thamdrup et al., 2006; Hamersley et al., 2007). These studies strongly question the traditional view that heterotrophic denitrification is the only significant driver of oceanic N-loss.

In the Arabian Sea OMZ, however, N-loss rates have rarely been measured directly. Despite the 
detection of signature lipid biomarker (Jaeschke et al., 2007) and gene sequences (Woebken et al., 2008) of anammox bacteria in the Arabian Sea OMZ, anammox activities had only been inferred (Devol et al., 2006) until recently. Nicholls et al. (2007) carried out incubation experiments using ${ }^{15} \mathrm{~N}$ labeled substrates and reported indications of very low anammox rates at three depths in the centralnortheastern (NE) Arabian Sea. A few years later, anammox rates were measured in the same region (Ward et al., 2009; Bulow et al., 2010). Interestingly, in the latter study, denitrification was reported to be the dominant and often the sole active N-loss process in most samples investigated. Nonetheless, as pointed out a few decades ago (Richards, 1965), if denitrification is the only active N-loss pathway, as a heterotrophic and presumably the major remineralization process in the OMZs, denitrification should liberate large amounts of ammonium $\left(\mathrm{NH}_{4}^{+}\right)$from the oxidation of organic matter. On the contrary, such expected $\mathrm{NH}_{4}^{+}$accumulations have not been observed in the OMZs (Cline and Richards, 1972; Codispoti and Christensen, 1985; Naqvi, 1987). Thus, the occurrence of anammox, which removes $\mathrm{NH}_{4}^{+}$while producing $\mathrm{N}_{2}$, is highly probable.

Anammox has been reported to co-occur with multiple N-cycling processes, including nitrification, nitrate reduction and dissimilatory nitrate/ nitrite reduction to ammonium (DNRA), in OMZs off the coasts of Peru and Namibia where denitrification was not detectable (Kartal et al., 2007a; Lam et al., 2009). Coupling of these reactions with anammox may in fact lead to the production of double- ${ }^{15} \mathrm{~N}$-labeled $\mathrm{N}_{2}\left({ }^{15} \mathrm{~N}^{15} \mathrm{~N}\right)$ and complicate data interpretation of isotope-pairing experiments. For instance, coupling between ammonia oxidation to nitrite and anammox can generate ${ }^{15} \mathrm{~N}^{15} \mathrm{~N}$ in ${ }^{15} \mathrm{NH}_{4}^{+}$ incubations in the presence of little ambient $\mathrm{NO}_{2}^{-}$ (Lam et al., 2007; Jensen et al., 2008). It is also theoretically possible to have ${ }^{15} \mathrm{~N}^{15} \mathrm{~N}$ produced from the interactions between anammox bacteria and organisms capable of DNRA in ${ }^{15} \mathrm{NO}_{2}^{-}$incubations, with results mimicking the signature of denitrification (Kartal et al., 2007a). In this case, ${ }^{15} \mathrm{NO}_{2}^{-}$can be reduced via DNRA to ${ }^{15} \mathrm{NH}_{4}^{+}$, which is then combined with ${ }^{15} \mathrm{NO}_{2}^{-}$at a $1: 1$ ratio through anammox to generate ${ }^{15} \mathrm{~N}^{15} \mathrm{~N}$ (Supplementary Figure S1). In the Arabian Sea OMZ, the occurrence of DNRA has been suggested on the basis of an excess production of single- ${ }^{15} \mathrm{~N}$-labeled $\mathrm{N}_{2}\left({ }^{14} \mathrm{~N}^{15} \mathrm{~N}\right)$ that could not be explained by either denitrification or anammox (Nicholls et al., 2007). However, the actual occurrence of DNRA and the presence of DNRA-capable microorganisms in the Arabian Sea remain unexplored.

Unlike the eastern tropical South Pacific where there is perennial upwelling except for El Niño years, biogeochemical processes in the Arabian Sea are heavily influenced by the seasonal reversal of monsoonal winds (Wiggert et al., 2005). Surface production is enhanced by upwelling along the western boundary and to a lesser extent in the central region during the Southwest monsoon (June-August), and by deep convective mixing in the north during the Northeast monsoon (DecemberFebruary; Marra and Barber, 2005). In the two intermonsoonal periods, conditions in the Arabian Sea approach oligotrophy. Because persistent oxygen-deficient conditions overlap with nitrite accumulations and large $\mathrm{N}$-deficits primarily in the central-NE Arabian Sea, most though not necessarily exclusive $\mathrm{N}$-loss activities have been postulated to occur in this part of the basin (Naqvi, 1991; Bange et al., 2005). In comparison, the mid-water column underlying the productive Omani upwelling zone rarely reaches complete anoxia, and so has not been considered important for N-loss (Naqvi, 1991; Bange et al., 2005). This apparent decoupling of N-loss and surface production in the Arabian Sea contrasts with other OMZs of eastern tropical Pacific and South Atlantic. However, no actual N-loss measurements have been made over the Omani shelf to date.

In this study, we examined the activities and mechanisms of $\mathrm{N}_{2}$ production in the Arabian Sea OMZ, through a combination of various ${ }^{15} \mathrm{~N}$-stableisotope-pairing experiments, expression analyses of biomarker functional genes and the enumeration of anammox bacterial cells. We conducted experiments for six depths through the vertical expanse of the OMZ (100-900 m) at seven stations, encompassing the Omani shelf and the central-NE Arabian Sea, to compare the relative importance of N-loss from these two regions.

\section{Materials and methods}

Water sampling and analyses of nutrients, particulate organic carbon and particulate nitrogen

Sampling took place in September/October 2007, just at the beginning of the autumn intermonsoon (Table 1). We followed the cruise track of the former US Joint Global Ocean Flux Study (Morrison et al., 1999; Figure 1). Water sampling was conducted with a conductivity-temperature-depth rosette equipped with $10 \mathrm{l}$ bottles on board the $R / V$ Meteor. The standard oxygen sensor of the conductivity-temperature-depth (Seabird) and an additionally mounted microsensor were used together to identify the OMZ. Besides, we deployed the highly sensitive STOX (Switchable Trace amount OXygen) sensor (Revsbech et al., 2009; detection limit: $90 \mathrm{nM}$ during our deployments) at stations 956-958 in the centralNE Arabian Sea. Water samples were analyzed for $\mathrm{NH}_{4}^{+}, \mathrm{NO}_{2}^{-}, \mathrm{NO}_{3}^{-}$and $\mathrm{PO}_{4}^{3-}$ (detection limits 20, 30, 100 and $100 \mathrm{nM}$, respectively) at 10 to $25-\mathrm{m}$ intervals for 12 stations (Figure 1). $\mathrm{NH}_{4}^{+}$and $\mathrm{NO}_{2}^{-}$concentrations were measured immediately after sampling using fluorometric and spectrophotometric techniques, respectively (Grasshoff, 1983; Holmes et al., 1999). Samples for $\mathrm{NO}_{3}^{-}$and $\mathrm{PO}_{4}^{3-}$ were stored frozen 
Table 1 Summary of ${ }^{15} \mathrm{~N}$-incubation experiments. Numbers in parentheses in the last column refer to the final concentrations of the ${ }^{15} \mathrm{~N}$ - and ${ }^{14} \mathrm{~N}$-species added into the incubations

\begin{tabular}{|c|c|c|c|c|}
\hline Station & Sampling date & Bottom depth (m) & Sampling depth (m) & Substrate additions $(\mu \mathrm{M})$ \\
\hline \multirow[t]{3}{*}{944} & 21 September & 653 & $120,150,200,450,500,550$ & ${ }^{15} \mathrm{NH}_{4}^{+}(5)$ \\
\hline & & & a & ${ }^{15} \mathrm{NH}_{4}^{+}+{ }^{14} \mathrm{NO}_{2}^{-}(5+5)$ \\
\hline & & & a & ${ }^{15} \mathrm{NO}_{2}^{-}+{ }^{14} \mathrm{NH}_{4}^{+}(5+5)$ \\
\hline \multirow[t]{2}{*}{946} & 22 September & 430 & $100,125,150,200,300,400$ & ${ }^{15} \mathrm{NH}_{4}^{+}(5)$ \\
\hline & & & a & ${ }^{15} \mathrm{NO}_{2}^{-}(5)$ \\
\hline \multirow[t]{4}{*}{949} & 24 September & 3985 & $150,175,375,500,675,900$ & ${ }^{15} \mathrm{NH}_{4}^{+}(5)$ \\
\hline & & & a & ${ }^{15} \mathrm{NO}_{2}^{-}(5)$ \\
\hline & & & a & ${ }^{15} \mathrm{NH}_{4}^{+}+{ }^{14} \mathrm{NO}_{2}^{-}(5+5)$ \\
\hline & & & a & ${ }^{15} \mathrm{NO}_{2}^{-}+{ }^{14} \mathrm{NH}_{4}^{+}(5+5)$ \\
\hline 950 & 25 September & 3916 & $150,175,300,500,700,900$ & b \\
\hline 953 & 27 September & 3549 & $125,225,350,500,700,900$ & b \\
\hline 955 & 29 September & 3254 & $115,200,300,500,700,900$ & b \\
\hline 957 & 30 September & 3242 & $110,200,300,500,700,900$ & $\mathrm{~b}$ \\
\hline
\end{tabular}

${ }^{a}$ Same depths as listed for the one above.

${ }^{\text {bSame }}{ }^{15} \mathrm{~N}$ treatments as listed for St 949.
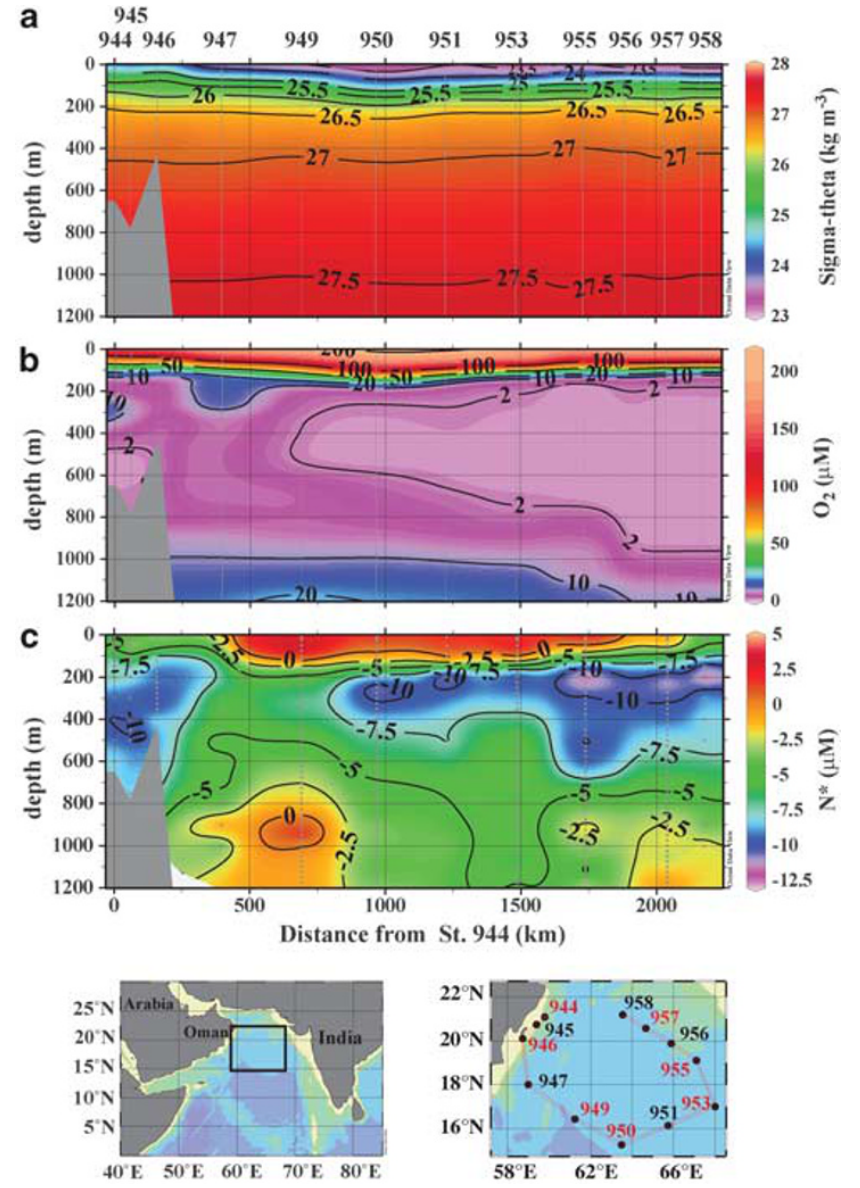

Figure 1 Distributions of (a) density, (b) oxygen and (c) $\mathrm{N}^{*}$ along the cruise track from the Omani coast to the central-northeastern Arabian Sea. Gray-filled circles denote sampling depths. Maps show sampling area, sampling locations and station numbers along our cruise track. Station numbers in red indicate sampling stations where ${ }^{15} \mathrm{~N}$-incubation experiments were conducted.

and measured spectrophotometrically (Grasshoff et al., 1999) with an autoanalyzer (TRAACS 800, Bran \& Lubbe, Hamburg, Germany) in a shore-based laboratory. Particulate organic carbon and nitrogen were collected by filtering 3-30l of seawater onto precombusted glass fiber filters. Particulate organic carbon and nitrogen were quantified on a flush combustion CNS Carlo Erba 1500 analyzer (Carlo Erba, Milan, Italy) after carbonate removal with $1 \mathrm{M} \mathrm{HCl}$.

\section{${ }^{15} \mathrm{~N}$-isotope pairing experiments}

Time-series ${ }^{15} \mathrm{~N}$-incubation experiments were carried out to determine $\mathrm{N}$-loss rates with various ${ }^{15} \mathrm{~N}$ - and ${ }^{14} \mathrm{~N}$-amendments, following previously described protocols (Dalsgaard et al., 2003; Kuypers et al., 2005). Different combinations of ${ }^{15} \mathrm{~N}$-labeled and unlabeled $\mathrm{NH}_{4}^{+}$and/or $\mathrm{NO}_{2}^{-}$were added to helium-purged seawater samples, and dispensed into Exetainer vials (Labco, High Wycombe, Buckinghamshire, UK) for incubation (Table 1). Purging with helium removed $\mathrm{O}_{2}$ to below the detection limit of an oxygen microsensor $(\leqslant 0.5 \mu \mathrm{M}$; MPI, Bremen, Germany). Samples were incubated at in situ temperature and in the dark for about $0,6,12,24$ and $48 \mathrm{~h}$. Isotopic compositions and concentrations of the $\mathrm{N}_{2}$ and $\mathrm{N}_{2} \mathrm{O}$ produced were analyzed on a gas chromatographyisotope ratio mass spectrometer (Fisons VG Optima, Fison, Manchester, UK). Afterwards, net DNRA rates were determined as the net accumulation of ${ }^{15} \mathrm{NH}_{4}^{+}$ from the same ${ }^{15} \mathrm{NO}_{2}^{-}$incubations. The isotopic composition of $\mathrm{NH}_{4}^{+}$was analyzed after chemical conversion into $\mathrm{N}_{2}$ with alkaline hypobromite (NaOBr; Warembourg, 1993). Further details are provided in Supplementary SI Text.

All rates were derived from linear regressions of ${ }^{15} \mathrm{~N}$-production $\left(\mathrm{N}_{2}, \mathrm{~N}_{2} \mathrm{O}\right.$ or $\left.\mathrm{NH}_{4}^{+}\right)$as a function of time, and only productions remaining linear without lag-phase and with slopes significantly greater than zero (one- or two-tailed $t$-tests, $P<0.05$ ) were reported (unless otherwise stated; detection limits: 150-200 pM per day, $0.5 \mathrm{nM}$ per day and $0.5 \mathrm{nM}$ per day for $\mathrm{N}_{2}, \mathrm{~N}_{2} \mathrm{O}$ and $\mathrm{NH}_{4}^{+}$, respectively). Anammox and denitrification rates were calculated from the 
regression slopes and the mole fractions of ${ }^{15} \mathrm{~N}$ in substrate pools (Thamdrup and Dalsgaard, 2002; Thamdrup et al., 2006; Supplementary SI Text). In the case of DNRA-anammox coupling, total anammox rates were calculated in a similar manner as in nitrification-anammox coupling (Jensen et al., 2008; Supplementary SI Text).

\section{Molecular ecological analyses}

Anammox bacteria were enumerated via catalyzed reporter deposition-fluorescence in situ hybridization (CARD-FISH; Pernthaler et al., 2002) with $16 \mathrm{~S}$ rRNA targeted probes BS820/BS820c (Hamersley et al., 2007; Supplementary SI Text). For simultaneous DNA and RNA extractions, seawater samples (10-15l) were filtered through Sterivex filters $(0.22 \mu \mathrm{m}$ pore size, Millipore $\mathrm{GmbH}$, Schwalbach, Germany) and stored at $-80^{\circ} \mathrm{C}$ until extraction (Supplementary SI Text). The biomarker functional genes for anammox (Scalindua-type $c d_{1}$-nitrite reductase or nirS), denitrification (denitrifier-nirS) and DNRA (cytochrome $c$ nitrite reductase, or $n r f A$ ) were quantified along with their expressions (transcription as mRNA) via real-time PCR, as previously described (Lam et al., 2009). Detailed protocols are provided in the Supplementary SI Text and Table S1. Clone libraries were also constructed for the expressed Scalindua-type and denitrifier-nirS, and the complementary DNA inserts were sequenced for phylogenetic analyses (Supplementary SI Text). Active gene transcription in unmanipulated seawater samples may provide independent support for an active process detected via manipulated incubation experiments, though the relationships between rates and gene expressions are not necessarily straightforward. This is because the different measurement types have vastly different detection limits, and that gene expression is also affected by physiological states, stresses and other (post)transcriptional factors. As a lot remains unexplored in the immense oceanic microbiome, we do not claim an exhaustive coverage of the functional gene targets by the selected primers.

\section{Results and discussion}

Physicochemical settings

Consistent with previous observations (Morrison et al., 1999), the water column at the time of our sampling became more strongly stratified from the western boundary towards the central basin (Figures 1a and b). Enhanced surface chlorophyll $a$, lower sea surface temperatures and shoaling of isopycnals westwards indicate residual upwelling near the Omani shelf (Figure 1a, Supplementary Figure S2). Oxygen concentrations declined sharply below $\sim 25-50 \mathrm{~m}$, and reached $<10 \mu \mathrm{M}$ at about $\sim 85-$ $100 \mathrm{~m}$. This oxygen-deficient OMZ extended to $\sim 1000 \mathrm{~m}$ depth (Figure 1b). Using the highly sensitive STOX sensor at stations 956-958, apparent anoxic conditions $(<90 \mathrm{nM})$ were found between $\sim 110$ and $800 \mathrm{~m}$ water depths (Supplementary Figure S3). Strong deficits of combined inorganic nitrogen relative to phosphate $\left(\mathrm{PO}_{4}^{3-}\right.$; Redfield et al., 1963), shown here as strongly negative $\mathrm{N}^{*}$ (in $\mu \mathrm{M}=\left[\mathrm{NO}_{3}^{-}+\mathrm{NO}_{2}^{-}+\mathrm{NH}_{4}^{+}\right]-16 \times\left[\mathrm{PO}_{4}^{3-}\right]+2.9 \mu \mathrm{mol} \mathrm{kg}{ }^{-1}$ $\times$ density in $\mathrm{kgl}^{-1}$; Gruber and Sarmiento, 1997), were the most pronounced in the upper part of the central-NE OMZ (Figure 1c), overlapping with the strong secondary nitrite maximum (Lam et al., 2011). Meanwhile, contrary to previous reports (Naqvi, 1991; Bange et al., 2005), N-deficits were also observed over the Omani shelf from $200 \mathrm{~m}$ water depth to the seafloor, coincident with apparently anoxic conditions $\left(<1-2 \mu \mathrm{M} \mathrm{O}_{2}\right.$ measured by a microsensor; Figures 1 and $2 b$ ), indicating past and/or present substantial N-loss from these waters.

\section{High N-loss via anammox over the Omani Shelf}

Indeed, significant N-loss activity was detected at the shelf stations (944 and 946). In both incubations with ${ }^{15} \mathrm{NH}_{4}^{+}$and ${ }^{15} \mathrm{NO}_{2}^{-}$, the production of single ${ }^{15} \mathrm{~N}-$ labeled $\mathrm{N}_{2}\left({ }^{14} \mathrm{~N}^{15} \mathrm{~N}\right)$ occurred right from the start and increased linearly with time over $48 \mathrm{~h}$ (for example, Figure 3). At the upper four sampled depths at station 946, and $120 \mathrm{~m}$ at station 944, all of the produced ${ }^{15} \mathrm{~N}$-labeled $\mathrm{N}_{2}$ in the ${ }^{15} \mathrm{NH}_{4}^{+}$incubations was recovered as ${ }^{14} \mathrm{~N}^{15} \mathrm{~N}$, whereas no production of ${ }^{15} \mathrm{~N}^{15} \mathrm{~N}$ was detected (Figures $2 \mathrm{~d}$ and 3a, Supplementary Figure S4a). Such exclusive production of ${ }^{14} \mathrm{~N}^{15} \mathrm{~N}$ without delay clearly indicated active occurrence of anammox. In parallel, there was comparable production of ${ }^{14} \mathrm{~N}^{15} \mathrm{~N}$ in the ${ }^{15} \mathrm{NO}_{2}^{-}$incubations, further verifying anammox activity (Figures $2 \mathrm{~d}$ and $3 \mathrm{~b}$ ).

Similar to the findings in the Peruvian and Chilean OMZ (Thamdrup et al., 2006; Hamersley et al., 2007), anammox rates determined from both ${ }^{15} \mathrm{~N}$-incubations were the highest in the upper OMZ over the shelf $\left(\sim 2.8 \mathrm{nmol}\right.$ of $\mathrm{N}_{2} \mathrm{l}^{-1}$ per day at station 944; $21-39 \mathrm{nmol}$ of $\mathrm{N}_{2} \mathrm{l}^{-1}$ per day at station 946), coincident with local maxima of $\mathrm{NH}_{4}^{+}$and $\mathrm{NO}_{2}^{-}$ (Figures 2c; Supplementary Table S2). Anammox rates dropped considerably to $\sim 1 \mathrm{nmol}$ of $\mathrm{N}_{2} \mathrm{l}^{-1}$ per day below $200 \mathrm{~m}$ at station 946 , where $\mathrm{NO}_{2}^{-}$returned to low levels. Anammox bacterial abundance, as measured via CARD-FISH, showed a similar vertical distribution to anammox rates (Figure 2e,d) (Spearman $R=0.766, \quad P<0.05$ and $R=0.755$, $P<0.05$ for rates from ${ }^{15} \mathrm{NH}_{4}^{+}$and ${ }^{15} \mathrm{NO}_{2}^{-}$incubations, respectively). Expression of the anammox functional gene biomarker, Scalindua-nirS, which encodes for the anammox (Scalindua)-specific cytochrome $c d_{1}$-containing nitrite reductase (Strous et al., 2006), was detectable at most depths examined, with the highest level found in the upper OMZ (Figure 2e, Supplementary Figure S5). Phylogenetic analyses revealed that the Arabian Sea expressed Scalindua-nirS sequences formed two tight clusters with some South China Sea sediment clones, 

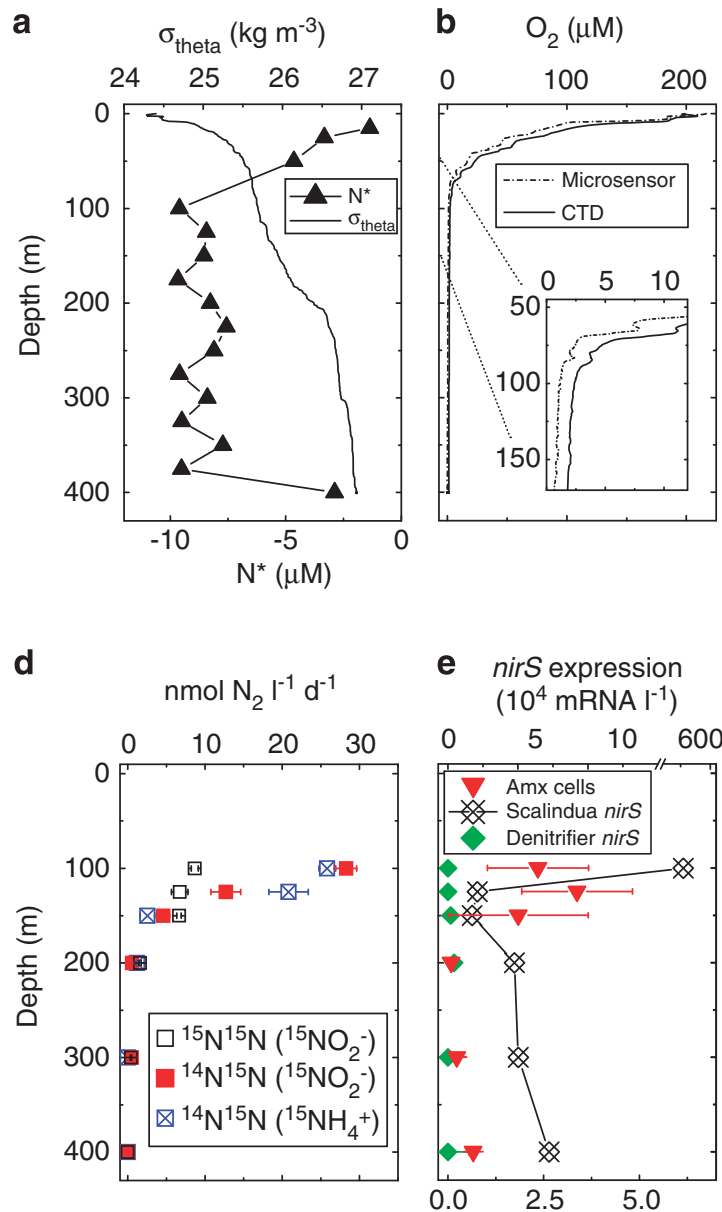

Anammox cells $\left(10^{6} \mathrm{I}^{-1}\right)$

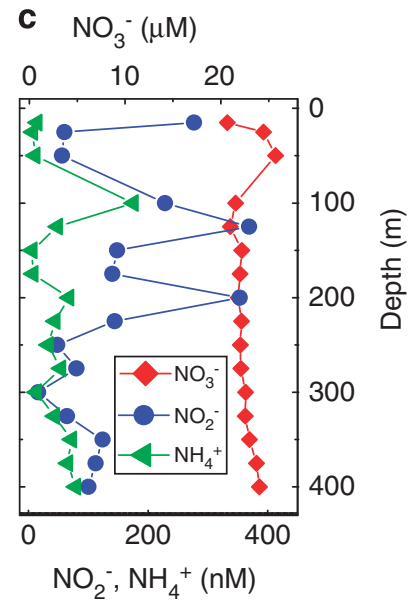

f $_{15} \mathrm{NH}_{4}^{+}\left(\mathrm{nmol} \mathrm{Nl^{-1 }} \mathrm{d}^{-1}\right)$

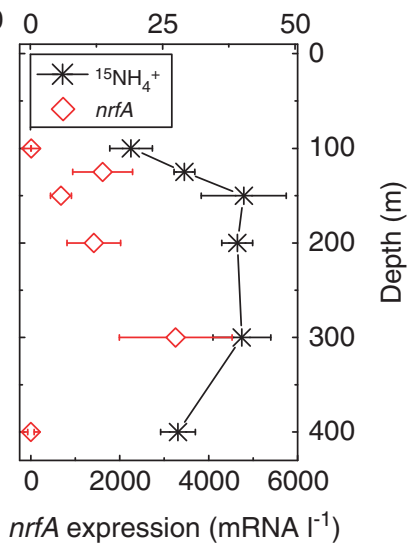

Figure 2 Vertical distribution of (a) potential density anomaly $\left(\sigma_{\theta}\right)$ and $\mathrm{N}^{*}$, (b) oxygen, (c) inorganic nitrogen, $(\mathbf{d}){ }^{14} \mathrm{~N}^{15} \mathrm{~N}$ and ${ }^{15} \mathrm{~N}^{15} \mathrm{~N}$ production rates (mean \pm s.e.) in various ${ }^{15} \mathrm{~N}$-incubations, (e) anammox bacterial abundance (mean \pm s.e.) measured by CARD-FISH and the expression (mean \pm s.e.) of anammox (Scalindua-type) and denitrifier $c d_{1}$-containing nitrite reductase nirS genes, and (f) DNRA rates (mean \pm s.e.) as net ${ }^{15} \mathrm{NH}_{4}^{+}$production from ${ }^{15} \mathrm{NO}_{2}^{-}$and expression of the corresponding biomarker functional gene, nrf $A$ (mean \pm s.e.) —all measured at station 946 .

whereas they were clearly distinct from the Peruvian OMZ cluster (71-90\% similarity) and the cultured Candidatus Scalindua sp. T23 (81-91\%; Supplementary Figure S6). This pattern is consistent with the 16S rRNA-based phylogeny (Woebken et al., 2008). In fact, with support from internal transcribed spacer sequence analyses, Arabian Sea anammox bacteria seem to form a novel species Candidatus Scalindua arabica (Woebken et al., 2008) that cannot be targeted by the oligonucleotide Amx820 (Schmid et al., 2000), commonly used to quantify anammox bacteria in environmental studies (for example, Ward et al., 2009).

Interestingly, there was substantial production of ${ }^{15} \mathrm{~N}^{15} \mathrm{~N}$ without lag in the ${ }^{15} \mathrm{NO}_{2}^{-}$incubations for most depths at station 946, which is normally taken as an evidence for concurrent denitrification activity (Figures 2d and $3 \mathrm{~b}$ ). The ${ }^{15} \mathrm{~N}^{15} \mathrm{~N}$ production rates decreased with depth, from $8.7 \mathrm{nmol}$ of $\mathrm{N}_{2} \mathrm{l}^{-1}$ per day at $100 \mathrm{~m}$ to $0.41 \mathrm{nmol}$ of $\mathrm{N}_{2} \mathrm{l}^{-1}$ per day at $300 \mathrm{~m}$ (Figure 2d). Nevertheless, if denitrification and anammox co-occurred, anammox bacteria likely depended on denitrification for the released $\mathrm{NH}_{4}^{+}$ from organic matter. Consequently, the proportional contribution of anammox to total $\mathrm{N}_{2}$ production would be constrained by the stoichiometric ratios of organic matter remineralized during denitrification (Dalsgaard et al., 2003). Assuming a C:N:P ratio of 106:16:1 in the organic matter (Redfield et al., 1963), anammox should in theory account for $29 \%$ of the total $\mathrm{N}_{2}$ production (Supplementary SI text), or $\leqslant 50 \%$ of total $\mathrm{N}_{2}$ production in the extreme case when only proteins were remineralized (Van Mooy et al., 2002; Dalsgaard et al., 2003). Instead, anammox contributed to $41-77 \%$ of total $\mathrm{N}_{2}$ production in our samples, suggesting that additional or alternative pathways were at play. The expression of the denitrifier-nirS, a biomarker functional gene encoding $c d_{1}$-containing nitrite reductase specific for denitrifiers, was not detectable at most depths at station 946 (Figure 2e). Neither detectable was the production of ${ }^{15} \mathrm{~N}-\mathrm{N}_{2} \mathrm{O}$ from ${ }^{15} \mathrm{NO}_{2}^{-}$, further pointing 

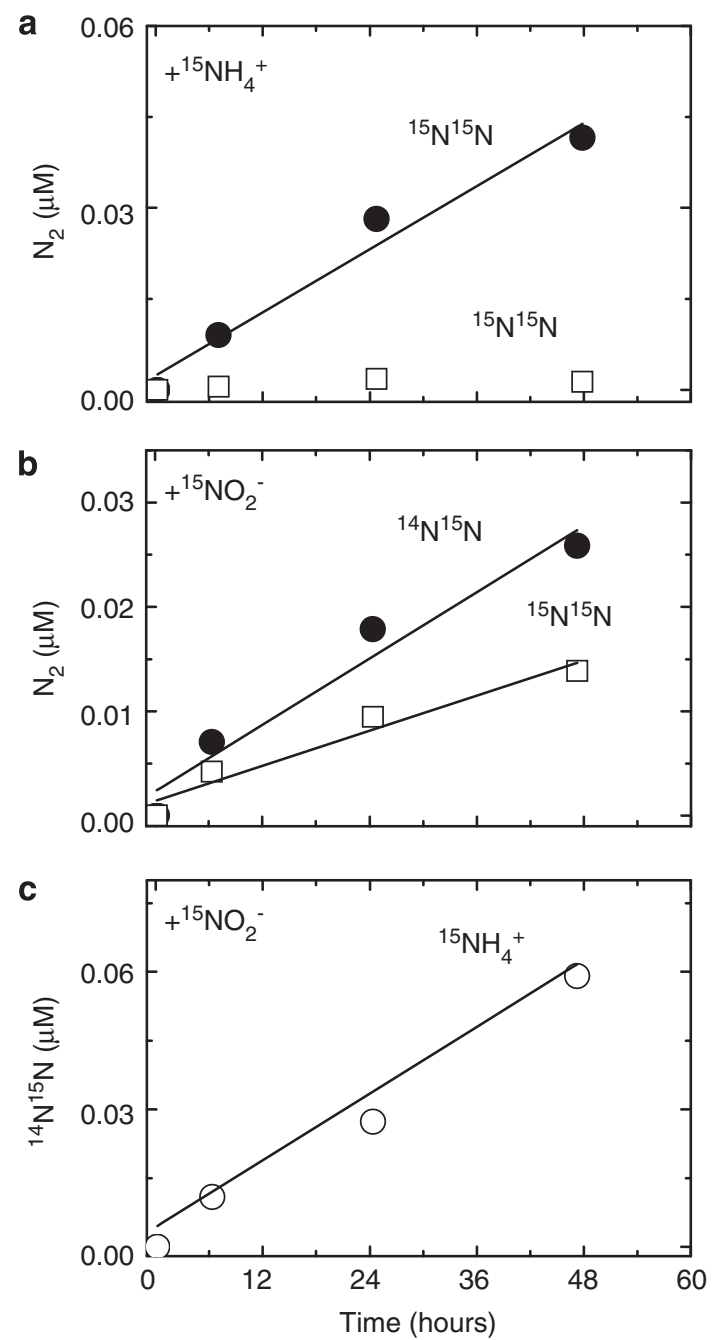

Figure 3 Examples of the linear production of ${ }^{15} \mathrm{~N}$-labeled $\mathrm{N}_{2}$ during incubations (a) with ${ }^{15} \mathrm{NH}_{4}^{+}$and (b) with ${ }^{15} \mathrm{NO}_{2}^{-}$. (c) DNRA measured as linear production of ${ }^{15} \mathrm{NH}_{4}^{+}$in the same ${ }^{15} \mathrm{NO}_{2}^{-}$incubations. Production rates of ${ }^{14} \mathrm{~N}^{15} \mathrm{~N},{ }^{15} \mathrm{~N}^{15} \mathrm{~N}$ and ${ }^{15} \mathrm{NH}_{4}^{+}$were calculated from the slopes in linear regression analyses. Data came from $125 \mathrm{~m}$ at station 946 over the Omani shelf.

to only low, if any, denitrification activity. Similarly, although ${ }^{15} \mathrm{~N}^{15} \mathrm{~N}$ production was detected at $120 \mathrm{~m}$ at station 944, it only occurred after a 14-h lag (Supplementary Table S1), whereas denitrifier-nirS expression and ${ }^{15} \mathrm{~N}-\mathrm{N}_{2} \mathrm{O}$ were not detected.

\section{DNRA-anammox coupling}

Substantial ${ }^{15} \mathrm{NH}_{4}^{+}$production from the ${ }^{15} \mathrm{NO}_{2}^{-}$pool indicates high net DNRA rates over the Omani shelf, with $\leqslant 40 \pm 5.5$ and $3.55 \pm 0.40 \mathrm{nmol}$ of $\mathrm{N}^{-1}$ per day measured at station 946 (Figures 2d,f and 3c) and station 944 (at $120 \mathrm{~m}$ with $\sim 5 \mathrm{~h}$ lag), respectively, where high anammox rates were also measured (Supplementary Table S2-3). These net DNRA rates were in the upper range of those reported for the Peruvian OMZ (Lam et al., 2009). Further evidence for DNRA came from the significantly correlating
(Spearman $R=0.538, P<0.01$ ) expression of $n r f A$, the biomarker functional gene encoding the enzyme cytochrome $c$ nitrite reductase that is essential in the DNRA reaction (Figure 2f, Supplementary Figure S5c, f). Together, the relatively high net DNRA rates, the consistently detectable active expression of $n r f A$ and Scalindua-nirS versus the sporadically detected low denitrifier-nirS expression, strongly suggest that the ${ }^{15} \mathrm{~N}^{15} \mathrm{~N}$ production resulted from the reduction of ${ }^{15} \mathrm{NO}_{2}^{-}$to ${ }^{15} \mathrm{NH}_{4}^{+}$, followed by a one-to-one combination of the produced ${ }^{15} \mathrm{NH}_{4}^{+}$and the added ${ }^{15} \mathrm{NO}_{2}^{-}$through anammox (Supplementary Figure S1). Although heterotrophic denitrification is thermodynamically more favorable than DNRA, a recent study using pure cultures of denitrifying and ammonifying (DNRA capable) bacteria revealed that the former conserved less energy and so had lower growth yields than ammonifying bacteria (4.6-6 $\mathrm{g}$ biomass per mol of $\mathrm{NO}_{2}^{-}$by denitrifiers versus $8.4 \mathrm{~g}$ by ammonifiers; Strohm et al., 2007). Hence, DNRA and anammox bacteria (growth yield 1.3-2 g biomass per mol $\mathrm{e}^{-}$-acceptor; Strous et al., 2006) acting together could have an energetic advantage over denitrifiers in the competition for substrates in oceanic OMZs.

Both measured DNRA rates and nrfA expression increased with depth in the upper OMZ at station 946, corresponding to a decrease in ambient $\mathrm{NH}_{4}^{+}$ levels. The ${ }^{15} \mathrm{~N}$ mole fraction of $\mathrm{NH}_{4}^{+}$resulting from DNRA is estimated to increase from $24 \%$ at $100 \mathrm{~m}$ to $61 \%$ at $150 \mathrm{~m}$, which reflects an increase in the proportion of anammox activity fueled by DNRA (Supplementary SI text). In other words, when ambient $\mathrm{NH}_{4}^{+}$is low and DNRA is highly active, the generated $\mathrm{NH}_{4}^{+}$by DNRA becomes more important for anammox. A tight DNRA-anammox coupling can then produce ${ }^{15} \mathrm{~N}^{15} \mathrm{~N}$ from ${ }^{15} \mathrm{NO}_{x}^{-}$, a signal that could easily be mistaken as a signature of denitrification only (Kartal et al., 2007a). Meanwhile, deeper in the water column where $\mathrm{NH}_{4}^{+}$was scarce and no N-loss activity was detected, the calculated $\mathrm{NH}_{4}^{+}$turnover (generation) due to DNRA alone was rather short (2-3 days). This might indicate additional in situ $\mathrm{NH}_{4}^{+}$assimilation, or large advective losses due to stronger current regimes over shelf regions that have not been simulated in our incubation experiments, whereas substrate stimulation in DNRA rate measurements were unlikely given the high availability of ambient nitrate.

Nevertheless, at two out of six depths (100 and $200 \mathrm{~m}$ ) at station 946, DNRA-anammox coupling was insufficient to fully explain the observed \% of ${ }^{15} \mathrm{~N}^{15} \mathrm{~N}$ in total $\mathrm{N}_{2}$ production from ${ }^{15} \mathrm{NO}_{2}^{-}$. The observed 23 and $74 \%$ at 100 and $200 \mathrm{~m}$, respectively, were double those of the expected 10 and $34 \%$ based on DNRA and anammox rates and the ambient $\mathrm{NH}_{4}^{+}$ concentrations (Supplementary SI Text). Part of this ${ }^{15} \mathrm{~N}^{15} \mathrm{~N}$ production could probably be explained by intracellular DNRA-anammox coupling by 
anammox bacteria themselves, which has not been accounted for in the above calculations. Such a capability has been shown in cultures (Kartal et al., 2007a) though it awaits verification in environmental studies. Alternatively, it might be partly attributable to denitrification, which would be in concordance with the detectable denitrifier-nirS expression at 150 and $200 \mathrm{~m}$. Sequence analyses of these expressed denitrifier-nirS, as amplified with the primers nirS1F-6R (Braker et al., 1998) and subsequently cloned, revealed relatively low diversity (only six OTUs based on 97\% nucleotide sequence cutoff) out of the 87 obtained sequences (Supplementary Figure S6), in contrast with the high diversity observed at the DNA level in a nearby region (Jayakumar et al., 2009). Most sequences were affiliated with Paracoccus denitrificans and Roseobacter denitrificans, whereas three OTUs were more closely related to other environmental sequences, including some previously retrieved from the Arabian Sea.

Low and sporadic N-loss in the central-NE OMZ In the central-NE Arabian Sea OMZ (stations 950, 953, 955 and 957), contrary to the expected high N-loss activities (Naqvi, 1991; Bange et al., 2005), $\mathrm{N}_{2}$ production was mostly undetectable except for perhaps 1-2 sporadic depths at each station (Supplementary Figure S4 c-f). Only at station 949, just outside the prominent secondary nitrite maximum, was anammox detected right below the oxycline $(150 \mathrm{~m})$ as significant ${ }^{14} \mathrm{~N}^{15} \mathrm{~N}$ productions in all four sets of incubations: ${ }^{15} \mathrm{NH}_{4}^{+},{ }^{15} \mathrm{NO}_{2}^{-}$, ${ }^{15} \mathrm{NH}_{4}^{+}+{ }^{14} \mathrm{NO}_{2}^{-}$and ${ }^{15} \mathrm{NO}_{2}^{-}+{ }^{14} \mathrm{NH}_{4}^{+}$(Supplementary Figure S4b, Supplementary Table S2). The detectable $\mathrm{N}_{2}$ production at the other central-NE stations only appeared in the form of ${ }^{14} \mathrm{~N}^{15} \mathrm{~N}$, and lacked consistency over the four different ${ }^{15} \mathrm{~N}$-treatments (Supplementary Figure S4 c-f). Although experiments with ${ }^{15} \mathrm{NH}_{4}^{+}$alone almost never yielded any ${ }^{15} \mathrm{~N}$-labelled $\mathrm{N}_{2}$ to unambiguously confirm anammox activity, there was no production of ${ }^{15} \mathrm{~N}^{15} \mathrm{~N}$ from ${ }^{15} \mathrm{NO}_{2}^{-}\left( \pm{ }^{14} \mathrm{NH}_{4}^{+}\right)$without initial time lag to verify in situ denitrification either. When detected, the rates ( $\leqslant 1 \mathrm{nmol}$ of ${ }^{14} \mathrm{~N}^{15} \mathrm{Nl}^{-1}$ per day) were close to the detection limit, and were often found with both substrates $\left(\mathrm{NH}_{4}^{+}\right.$and $\left.\mathrm{NO}_{2}^{-}\right)$added. Hence, these $\mathrm{N}$-loss rates in the central-NE Arabian Sea should be regarded as potential rather than in situ rates. Anammox potentials were further corroborated by the consistently detectable expression of ScalinduanirS (Supplementary Figure S5), and the presence of anammox bacteria identified via CARD-FISH, though their cellular abundance was too low to give reliable microscopic cell counts $(<0.1 \%$ total microbial abundance). These results are consistent with another recent study conducted during the same intermonsoon period, when patchy anammox activity was reported at two stations nearby (Ward et al., 2009; Bulow et al., 2010). DNRA-anammox coupling was not evident in the central-NE basin at the time of our sampling. DNRA rates were assessed at two central-NE stations (957 and 955), and were only detectable at two depths $(200 \mathrm{~m}$ at station 955 and $900 \mathrm{~m}$ at station 957) with very low rates near detection limit.

Despite the greater abundance of denitrifiers over anammox bacteria detected at the gene level, which agreed with the recent study in the central-NE Arabian Sea (Ward et al., 2009), there was only low to undetectable active expression of the dentrifiernirS gene (Supplementary Figure S5). Although the primers (Michotey et al., 2000; Throbäck et al., 2004) used for quantification (quantitative PCR) may not cover all environmental nirS sequences and thereby underestimated denitrifiers at the gene level, these primers have been tested to exhibit high specificity (Throbäck et al., 2004) and cover the vast majority of the expressed complementary DNA sequences except for two OTUs (six sequences) retrieved in our study. In contrast, the primer nirS3R (Braker et al., 1998) used to quantify denitrifiers by Ward et al. (2009) has sequence mismatches with all complementary DNA sequences obtained in our study, as well as with a fair number of cultured strains (Braker et al., 1998) and published environmental sequences (for example, 67 out of the 113 denitrifier sequences shown in Supplementary Figure S6), including some retrieved from the Arabian Sea. If the stringency of quantitative PCR conditions is relaxed to cover more sequences, this primer may additionally bind to a second region 18 bases downstream and result in double or unspecific quantification. Therefore, the primer nirS3R is unsuitable and not chosen for use in quantitative PCR. Overall, our gene expression analyses showed little indication of actively expressed denitrifiernirS in these waters, albeit new designs for more universal nirS-targeting primers suitable for quantitative PCR, or the use of PCR-independent methods, such as metagenomics/metatranscriptomics, are necessary for a more comprehensive appraisal.

Altogether, the lack of readily detectable denitrifier-nirS expression at most stations and depths in the central-NE Arabian Sea, was in line with the absence of any significant ${ }^{15} \mathrm{~N}^{15} \mathrm{~N}$ production detected from ${ }^{15} \mathrm{NO}_{2}^{-}$incubations, as well as the lack of measurable ${ }^{15} \mathrm{~N}$-labeled $\mathrm{N}_{2} \mathrm{O}$ production. Interestingly, in the incubations with ${ }^{15} \mathrm{NO}_{2}^{-}\left( \pm{ }^{14} \mathrm{NH}_{4}^{+}\right)$at these stations, an abrupt $\mathrm{N}_{2}$ production often occurred after $24-50 \mathrm{~h}$ time lag (Supplementary Figure S7). This sharp delayed $\mathrm{N}_{2}$ production included both ${ }^{14} \mathrm{~N}^{15} \mathrm{~N}$ and ${ }^{15} \mathrm{~N}^{15} \mathrm{~N}$. Although denitrification might be inhibited by $\geqslant 2-4 \mu \mathrm{M}$ of $\mathrm{O}_{2}$ (Devol, 1978) and anammox by $\geqslant 13 \mu \mathrm{M}$ (Jensen et al., 2008), $<90 \mathrm{nM}$ of $\mathrm{O}_{2}$ was detected in the core of the central-NE OMZ in situ with the STOX sensor, and $\leqslant 0.5 \pm 0.09 \mu \mathrm{M} \mathrm{O}_{2}$ measured in the exetainers with an oxygen microsensor in the current and previous studies $(<0.2 \mu \mathrm{M}$ by Dalsgaard et al., 2003 and Jensen et al., 2008). Hence, oxygen 
inhibition of N-loss processes at sub-micromolar levels can most likely be discounted. Instead, although reflecting an apparent artifact after prolonged incubation and not counted as rates here, the lagged ${ }^{15} \mathrm{~N}^{15} \mathrm{~N}$ production from ${ }^{15} \mathrm{NO}_{2}^{-}\left( \pm{ }^{14} \mathrm{NH}_{4}^{+}\right)$ likely indicated stimulated denitrification after long incubationhours, and would agree with the observed high gene abundance but inconsistent expression of denitrifier-nirS. Similarly, time lags could be observed in the recent study by Ward et al. (2009) that was further detailed in Bulow et al. (2010). In that study, there was no significant ${ }^{15} \mathrm{~N}$-labeled $\mathrm{N}_{2}$ production from ${ }^{15} \mathrm{NO}_{2}^{-}$nor from ${ }^{46} \mathrm{~N}_{2} \mathrm{O}$ in the first $24 \mathrm{~h}$ of incubation, at least for the representative sampled depth shown and for which their highest denitrification rate $(25 \pm 9.1 \mathrm{nmol}$ of $\mathrm{N}_{2} \mathrm{l}^{-1}$ per day) was reported. In other words, despite the persistent denitrification potentials present in the central-NE Arabian Sea OMZ, there is limited evidence for their in situ activities. However, active denitrification cannot be excluded at other times, as it is likely subjected to strong spatiotemporal variabilities.

\section{Distribution and variability of N-loss in the Arabian Sea}

Considering the entire basin of the Arabian Sea, our measured anammox rates ranged from undetectable to $27 \pm 1.1 \mathrm{nmol}$ of $\mathrm{N}_{2} \mathrm{l}^{-1}$ per day (from ${ }^{15} \mathrm{NH}_{4}^{+}$ incubations), or up to $38 \pm 1.9 \mathrm{nmol}$ of $\mathrm{N}_{2} \mathrm{l}^{-1}$ per day taking into account the coupling with DNRA (from ${ }^{15} \mathrm{NO}_{2}^{-}$incubations; Table 2). When integrated over the depth range of the OMZ, the highest N-loss due to anammox occurred over the Omani shelf at a rate of up to $4.5 \pm 0.4 \mathrm{mmol}$ of $\mathrm{N} \mathrm{m}^{-2}$ per day (Figure 4), comparable with those reported for the Namibian and Peruvian shelves (Kuypers et al., 2005; Hamersley et al., 2007). Together with previous findings of substantial anammox, but low to undetectable denitrification in other marine oxygen-deficient waters (Kuypers et al., 2005; Thamdrup et al., 2006; Hamersley et al., 2007; Jensen et al., 2008), the current study confirms the importance of anammox in global oceanic N-loss. At just about $500 \mathrm{~km}$ offshore, the depth-integrated $\mathrm{N}$-loss was reduced by two orders of magnitude, and down to only potential rates in the central-NE basin (Figure 4). Even if the measured potential rate profiles were integrated for the central-NE OMZ,

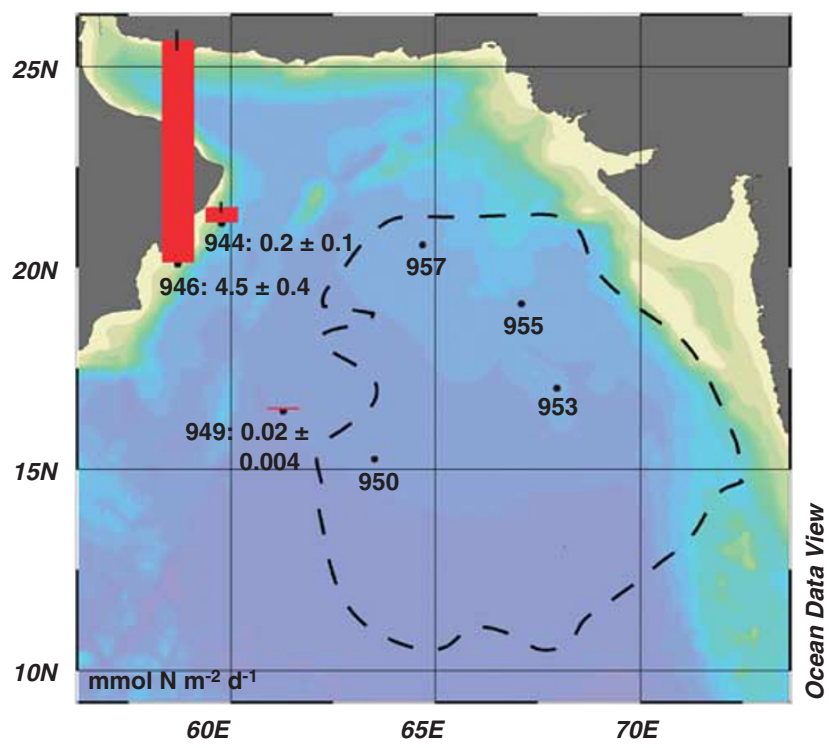

Figure 4 Estimates of depth-integrated anammox rates ( \pm s.e.) measured in Arabian Sea OMZ in this study. Rates are calculated from incubations with ${ }^{15} \mathrm{NO}_{2}^{-}$, and only rates that showed consistency across various isotope combinations have been included. The dashed line marks the approximate geographical extent of the prominent secondary nitrite maximum $(\geqslant 0.5 \mu \mathrm{M})$ as the postulated major denitrification region in the Arabian Sea (Naqvi, 1991).

Table 2 Summary of volumetric and depth-integrated rates of anammox and denitrification in various studies of oceanic OMZs.

\begin{tabular}{|c|c|c|c|c|c|}
\hline & $\begin{array}{c}\text { Anammox } \\
\text { (nmol of } N_{2} I^{-1} \text { per day) }\end{array}$ & $\begin{array}{c}\text { Denitrification } \\
\text { (nmol of } \mathrm{N}_{2} l^{-1} \text { per day) }\end{array}$ & $\begin{array}{c}\text { Anammox } \\
\text { (mmol of } \mathrm{N} \mathrm{m}^{-2} \text { per day) }\end{array}$ & $\begin{array}{c}\text { Denitrification } \\
\text { (mmol of } \mathrm{N} \mathrm{m}^{-2} \text { per day) }\end{array}$ & Reference \\
\hline Off Chile & $2-17^{\mathrm{a}}$ & ND & $0.6-1.5^{\mathrm{b}}$ & & Thamdrup et al., 2006 \\
\hline Off Peru ${ }^{\mathrm{c}}$ & $0-164^{\mathrm{a}}$ & ND & $1.3-34$ & & Hamersley et al., 2007 \\
\hline Off Namibia & $10-180^{\mathrm{a}}$ & ND & $1-5$ & & Kuypers et al., 2005 \\
\hline Arabian Sea & & & & $\sim 1.3-1.9^{\mathrm{d}}$ & Devol et al., 2006 \\
\hline Arabian Sea & $0.2-4.3$ & $0.2-25$ & & & Ward et al., 2009 \\
\hline Arabian Sea & $0-27^{\mathrm{a}}$ & & $0.02-3.2^{\mathrm{a}}$ & & This study \\
\hline Arabian Sea & $0-38^{\mathrm{e}}$ & & $0.02-4.5^{\mathrm{e}}$ & & This study \\
\hline
\end{tabular}

Abbreviations: ND, not detectable; OMZs, oxygen minimum zones.

${ }^{\text {a Rates from }}{ }^{15} \mathrm{NH}_{4}^{+}$incubations.

${ }^{\mathrm{b}}$ Approximate rates as calculated based on rates from Figure 5 of Thamdrup et al. (2006). Anammox rates were integrated over a depth range of 30-175 $\mathrm{m}$ at two stations sampled within 3 days.

${ }^{\mathrm{c}}$ Potential rates calculated from non-substrate-limited ${ }^{15} \mathrm{NH}_{4}^{+}+{ }^{14} \mathrm{NO}_{2}^{-}$incubation.

${ }^{\mathrm{d}}$ Approximate rates as calculated based on rates from Figure 4 of Devol et al. (2006). The $\mathrm{N}^{-l o s s}$ rates were determined as the conversion of ${ }^{15} \mathrm{NO}_{3}^{-}$ to ${ }^{14} \mathrm{~N}^{15} \mathrm{~N}$ in incubated water samples from the open-ocean Arabian Sea. Therefore, denitrification measurements did not directly include $\mathrm{N}_{2}$ production by anammox, nor could anammox be excluded. Rates were integrated over a depth range of 150-350 m.

${ }^{\text {eRates from }}{ }^{15} \mathrm{NO}_{2}^{-}$incubations.

Depth-integrated rates were calculated as IR $=\sum_{n=1}\left(R_{n} h_{n}\right)$ where IR denotes the integrated rate, $R_{n}$ is the measured rate for depth interval $n$, and $h_{\mathrm{n}}$ denotes the height of the water column for interval $n$ (Dalsgaard et al., 2003). The boundary for each interval $n$ was demarcated by the midpoint between two consecutive measurements. The upper boundary was set at the depth where $\mathrm{O}_{2}<2 \mu \mathrm{M}$. 
there would be at most $0.3-0.6 \mathrm{mmol}$ of $\mathrm{N} \mathrm{m}^{-2}$ per day $\mathrm{N}$-loss. This finding of greater N-loss associated with the more productive upwelling waters toward the coast, on one hand coheres with observations from other OMZs that are also linked to upwelling systems (Kuypers et al., 2005; Hamersley et al., 2007). On the other hand, it contradicts with the conventional presumption of high N-loss in the central-NE Arabian Sea deduced from nitrite accumulation or N-deficits (Naqvi, 1991; Bange et al., 2005), and the moderate denitrification rates measured previously (Ward et al., 2009; Bulow et al., 2010).

The fact that high N-loss rates were obtained over the more productive Omani shelf waters suggested a close link between N-loss and the availability of organic matter. Indeed, our measured N-loss rates were significantly and positively correlated with surface particulate organic carbon (Spearman correlation $R=0.50, P<0.0001$ ) and particulate nitrogen (Spearman $R=0.53, \quad P<0.0005 ; \quad$ Supplementary Figure S8). Both anammox and denitrification have to rely on organic matter, either indirectly for the source of remineralized $\mathrm{NH}_{4}^{+}$by the former, or directly for sources of carbon and electrons by the latter or both (Kartal et al., 2007b). Thus, organic matter would be a logical controlling factor for $\mathrm{N}$-loss via either pathway. This is consistent with a study from the eastern tropical South Pacific where surface primary production and not oxygen appeared to be the primary factor regulating $\mathrm{N}$-loss (Lipschultz et al., 1990). Surface production in the Arabian Sea is heavily influenced by the seasonal monsoons, and nutrients are delivered to the open ocean via mesoscale eddies more than open-ocean Ekman pumping (Marra and Barber, 2005; Wiggert et al., 2005). Consequently, high spatiotemporal variabilities are especially apparent in the central$\mathrm{NE}$ region, as reflected in the patchiness in surface chlorophyll $a$ during our sampling period (Supplementary Figure S2; Lam et al., 2011). Over just a 2-month period around our sampling, a high degree of week-to-week patchiness could be seen especially in the central-NE Arabian Sea; whereas the effects of upwelling persisted westward until early October 2007 (Supplementary Figure S2b). The recent study by Ward et al. (2009) sampled in close proximity to stations 950 and 955 at 1 week after and before this study, respectively. They reported moderate N-loss rates through mainly denitrification. Although their observations might not have truly differed much from ours if the same criteria were used for rate calculations (for example, exclusion of data series with significant initial time lags), the disparities between the two studies may also be attributed to the high spatiotemporal variabilities in the Arabian Sea. The detected N-loss activity might reflect N-loss in response to episodic pulses of organic matter sinking from surface water. Therefore, the spatiotemporal variabilities of N-loss and $\mathrm{N}$-cycling in the Arabian Sea certainly require further assessment.

\section{Conclusions and perspectives}

Our current study reports for the first time a direct link between DNRA and anammox in the ocean through a production of ${ }^{15} \mathrm{~N}^{15} \mathrm{~N}$ from ${ }^{15} \mathrm{NO}_{2}^{-}$- signal easily mistaken as a signature for denitrification only. This DNRA-anammox coupling mediates the highest $\mathrm{N}$-loss rates reported at this time in the Arabian Sea, and was found in a hitherto overlooked region over the productive Omani shelf. By contrast, only low potential rates at best were detected in the presumed active N-loss zone in the central-NE OMZ. Despite being the world's thickest oceanic OMZ, the calculated depth-integrated N-loss from the Arabian Sea OMZ was only a fraction of that in the Peruvian OMZ (Table 2). This suggests that the common estimate of the Arabian Sea accounting for $\sim 20 \%$ of global oceanic N-loss is perhaps too high, and that the strongly negative $\mathrm{N}^{*}$, as a timeintegrated signal, might reflect an accumulation of low or episodic N-loss within a poorly ventilated water layer in the central-NE basin (Lam et al., 2011). Although we might have only captured a snapshot in space and time, if N-loss is indeed intimately linked to organic matter availability, considering the Omani upwelling being the most productive waters in the basin on an annual basis, the detected N-loss therein might represent a major contribution to the yearly N-budget that has so far been ignored. The observed DNRA-anammox coupling may also occur at the eastern and northern boundaries of the Arabian Sea, where the OMZ impinges on the Indian and Pakistani shelves underlying some relatively productive waters at least on a seasonal basis. These shelf regions may together be responsible for significant total N-loss that needs to be taken into N-budget calculations. Further studies with higher temporal and spatial resolutions are necessary to elucidate the true spatial extent of N-loss, and how exactly N-loss and the overall N-cycling respond to seasonality and short-term variabilities in the Arabian Sea, and whether there is a dominance or succession of N-loss mechanisms. Besides, our results highlight the need to examine possibly concurrent N-cycling processes together with N-loss in oxygen-deficient environments, as these concurrent processes may complicate reliable estimates of total N-loss.

\section{Acknowledgements}

We thank Gaute Lavik, Gabriele Klockgether, Daniela Franzke, Stefanie Pietsch, Vera Meyer (all from MPI$\mathrm{MM}$ ), Udo Huebner and Mark Metzke (University of Hamburg), as well as the captain and crew of $R / V$ Meteor (M74-1b), for their conscientious technical and logistical support. We are also grateful to Rudolf Amann for the access to his laboratory facilities. Funding came from the Max Planck Gesellschaft, Deutsche Forschungsgemeinschaft (No. KU1550/3-1; MMMK and PL), the Danish Research Council (MMJ), the BioGeosphere Program of the 
Netherlands Organisation for Scientific Research (MSMJ), and the Agouron Institute and the Gordon and Betty Moore Foundation (NPR).

\section{References}

Bange HW, Naqvi SWA, Codispoti LA. (2005). The nitrogen cycle in the Arabian Sea. Prog Oceanogr 65: 145-158.

Braker G, Fesefeldt A, Witzel KP. (1998). Development of PCR primer systems for amplification of nitrite reductase genes (nirK and nirS) to detect denitrifying bacteria in environmental samples. Appl Environ Microbiol 64: 3769-3775.

Bulow SE, Rich JJ, Naik HS, Pratihary AK, Ward BB. (2010). Denitrification exceeds anammox as a nitrogen loss pathway in the Arabian Sea oxygen minimum zone. Deep Sea Res I 57: 384-393.

Capone DG. (2000). The marine microbial nitrogen cycle. In: Kirchman DL (ed). Microbial Ecology of the Oceans. John Wiley and sons Inc.: New York, pp 455-492.

Cline JD, Richards FA. (1972). Oxygen deficient conditions and nitrate reduction in the Eastern Tropical North Pacific Ocean. Limnol Oceanogr 17: 885-900.

Codispoti LA, Brandes JA, Christensen JP, Devol AH, Naqvi SWA, Paerl HW et al. (2001). The oceanic fixed nitrogen and nitrous oxide budgets: moving targets as we enter the anthropocene? Scientia Marina 65: 85-105.

Codispoti LA, Christensen JP. (1985). Nitrification, denitrifcation and nitrous oxide cycling in the Eastern Tropical South Pacific Ocean. Marine Chem 16: $277-300$.

Dalsgaard T, Canfield DE, Petersen J, Thamdrup B, AcunaGonzalez J. (2003). $\mathrm{N}_{2}$ production by the anammox reaction in the anoxic water column of Golfo Dulce, Costa Rica. Nature 422: 606-608.

Devol A. (1978). Bacterial oxygen uptake kinetics as related to biological processes in oxygen deficient zones of the ocean. Deep Sea Res 25: 137-146.

Devol AH, Uhlenhopp AG, Naqvi SWA, Brandes JA, Jayakumar DA, Naik $\mathrm{H}$ et al. (2006). Denitrification rates and excess nitrogen gas concentrations in the Arabian Sea oxygen deficient zone. Deep Sea Res I 53: 1533-1547.

Grasshoff K. (1983). Determination of nitrite. In: Grasshoff K, Ehrhardt M, Kremling K (eds) Methods in Seawater Analyse. Wiley-VCH: Weinheim.

Grasshoff K, Ehrhardt M, Kremling K, Anderson LG. (1999). Methods of Seawater Analysis. Wiley: Weinheim.

Gruber N. (2004). The dynamics of the marine nitrogen cycle and its influence on atmospheric $\mathrm{CO}_{2}$ variations. In: Follows M, Oguz T (eds). The Ocean Carbon Cycle and Climate, NATO ASI Series. Kluwer Academic: Dordrecht, pp 97-148.

Gruber N, Sarmiento JL. (1997). Global patterns of marine nitrogen fixation and denitrification. Global Biogeochem Cy 11: 235-266.

Hamersley MR, Lavik G, Woebken D, Rattray JE, Lam P, Hopmans EC et al. (2007). Anaerobic ammonium oxidation in the Peruvian oxygen minimum zone. Limnol Oceanogr 52: 923-933.
Holmes RM, Aminot A, Kerouel R, Hooker A, Peterson BJ. (1999). A simple and precise method for measuring ammonium in marine and freshwater ecosystems. Can J Fish Aqaut Sci 56: 1801-1808.

Jaeschke A, Hopmans EC, Wakeham SG, Schouten S, Sinninghe Damsté JS. (2007). The presence of ladderane lipids in the oxygen minimum zone of the Arabian Sea indicates nitrogen loss through anammox. Limnol Oceanogr 52: 780-786.

Jayakumar A, Naqvi SWA, Ward BB. (2009). Distribution and relative quantification of key genes involved in fixed nitrogen loss from the Arabian Sea oxygen minimum zone. In: Wiggert JD, Hood RR, Naqvi SWA, Brink KH and Smith SL (eds). Indian Ocean Biogeochemical Processes and Ecological Variability. American Geophysical Union: Washington DC, USA, pp 187-203.

Jensen MM, Kuypers MMM, Lavik G, Thamdrup B. (2008). Rates and regulation of anaerobic ammonium oxidation and denitrification in the Black Sea. Limnol Oceanogr 53: 23-36.

Kartal B, Kuypers MMM, Lavik G, Schalk J, Op den Camp HJM, Jetten MSM et al. (2007a). Anammox bacteria disguised as denitrifyers: nitrate reduction to dinitrogen gas via nitrate and ammonium. Environ Microbiol 9: $635-642$.

Kartal B, Rattray J, van Niftrik LA, van de Vossenberg J, Schmid MC, Webb RI et al. (2007b). Candidatus 'anammoxoglobus propionicus' a new propionate oxidizing species of anaerobic ammonium oxidizing bacteria. Syst Appl Microbiol 30: 39-49.

Kuypers MMM, Lavik G, Woebken D, Schmid M, Fuchs BM, Amann R et al. (2005). Massive nitrogen loss from the Benguela upwelling system through anaerobic ammonium oxidation. Proc Natl Acad Sci USA 102: 6478-6483.

Lam P, Jensen MM, Kock A, Lettmann KA, Plancherel Y, Lavik $\mathrm{G}$ et al. (2011). Origin and fate of the secondary nitrite maximum in the Arabian Sea. Biogeosciences Discuss 8: 2357-2402.

Lam P, Jensen MM, Lavik G, McGinnis DF, Müller B, Schubert CJ et al. (2007). Linking crenarchaeal and bacterial nitrification to anammox in the Black Sea. Proc Natl Acad Sci USA 104: 7104-7109.

Lam P, Lavik G, Jensen MM, van de Vossenberg J, Schmid M, Woebken D et al. (2009). Revising the nitrogen cycle in the Peruvian oxygen minimum zone. Proc Natl Acad Sci USA 106: 4752-4757.

Lipschultz F, Wofse SC, Ward BB, Codispoti LA, Friederich G, Elkins JW. (1990). Bacterial transformations of inorganic nitrogen in the oxygen-deficient waters of the Eastern Tropical South Pacific Ocean. Deep Sea Res 37: 1513-1541.

Marra J, Barber RT. (2005). Primary productivity in the Arabian Sea: a synthesis of JGOFS data. Prog Oceanogr 65: 159-175.

Michotey V, Mejean V, Bonin B. (2000). Comparison of methods for quantification of cytochrome cd1-denitrifying bacteria in environmental marine samples. Appl Environ Microbiol 66: 1564-1571.

Morrison JM, Codispoti LA, Smith SL, Wishner K, Flagg C, Gardner WD et al. (1999). The oxygen minimum zone in the Arabian Sea during 1995. Deep Sea Res Part II Top Stud Oceanogr 46: 1903-1931.

Naqvi SWA. (1987). Some aspects of the oxygen-deficient conditions and denitrification in the Arabian Sea. J Marine Res 45: 1049-1072. 
Naqvi WA. (1991). Geographical extent of denitrification in the Arabian Sea in relation to some pphysical processes. Oceanol Acta 14: 281-290.

Nicholls JC, Davies CA, Trimmer M. (2007). Highresolution profiles and nitrogen isotope tracing reveal a dominant source of nitrous oxide and multiple pathways of nitrogen gas formation in the central Arabian Sea. Limnol Oceanogr 52: 156-168.

Pernthaler A, Pernthaler J, Amann R. (2002). Fluorescence in situ hybridization and catalysed reporter deposition for the identification of marine bacteria. Appl Environ Microbiol 68: 3094-3101.

Redfield A, Ketchum BH, Richards FA. (1963). The influence of organisms on the composition of sea-water. In: Hill MN (ed). The Sea. Wiley-Interscience: New York, pp 26-77.

Revsbech NP, Larsen LH, Gundersen JK, Dalsgaard T, Ulloa O, Thamdrup B. (2009). Determination of ultralow oxygen concentrations in oxygen minimum zones by the STOX sensor. Limn Oceanogr: Methods 7: 371-381.

Richards FA. (1965). Anoxic basins and fjords. In: Riley JP and Skirrow G (eds). Chemical Oceangraphy. Academic Press: London and New York, pp 611-645.

Schmid M, Twachtmann U, Klein M, Strous M, Juretschko S, Jetten M et al. (2000). Molecular evidence for genus level diversity of bacteria capable of catalyzing anaerobic ammonium oxidation. Syst Appl Microbiol 23: $93-106$.

Strohm TO, Griffin B, Zumft WG, Schink B. (2007). Growth yields in bacterial denitrification and nitrate ammonification. Appl Environ Microbiol 73: 1420-1424.

Strous M, Pelletier E, Mangenot S, Rattei T, Lehner A, Taylor MW et al. (2006). Deciphering the evolution and metabolism of an anammox bacterium from a community genome. Nature 440: 790-794.

Thamdrup B, Dalsgaard T. (2002). Production of $\mathrm{N}_{2}$ through anaerobic ammonium oxidation coupled to nitrate reduction in marine sediments. Appl Environ Microbiol 68: 1312-1318.

Thamdrup B, Dalsgaard T, Jensen MM, Ulloa O, Farias L, Escribano R. (2006). Anaerobic ammonium oxidation in the oxygen-deficient waters off northern Chile. Limnol Oceanogr 51: 2145-2156.

Throbäck IN, Enwall K, Jarvis A, Hallin S. (2004). Reassessing PCR primers targeting nirS, nirK and nosZ genes for community surveys of denitrifying bacteria with DGGE. FEMS Microbiol Ecol 49: 401-417.

Van Mooy BAS, Keil RG, Devol AH. (2002). Impact of suboxia on sinking particulate organic carbon: Enhanced carbon flux and preferential degradation of amino acids via denitrification. Geochim Cosmochim Ac 66: 457-465.

Ward BB, Devol A, Rich JJ, Chang BX, Bulow SE, Naik H et al. (2009). Denitrification as the dominant nitrogen loss process in the Arabian Sea. Nature 461: 78-81.

Warembourg FR. (1993). Nitrogen fixation in soil and plant system. In: Knowles R and Blackburn TH (eds). Nitrogen Isotopes Techniques. Academic Press: New York, pp 127-155.

Wiggert JD, Hood RR, Banse K, Kindle JC. (2005). Monsoon-driven biogeochemical processes in the Arabian Sea. Prog Oceanogr 65: 176-213.

Woebken D, Lam P, Kuypers MMM, Naqvi SWA, Kartal B, Strous $\mathrm{M}$ et al. (2008). A microdiversity study of anammox bacteria reveals a novel Candidatus Scalindua phylotype in marine oxygen minimum zones. Env Microbiol 10: 3106-3119.

Supplementary Information accompanies the paper on The ISME Journal website (http://www.nature.com/ismej) 